УДК 776.799
https://doi.org/10.36906/FKS-2021/54

Кориунова О.С., ORCID: 0000-0002-5602-3688

Новосибирский государственный университет экономики и управления, 2. Новосибирск, Россия

\title{
ИССЛЕДОВАНИЕ ПСИХОЛОГИЧЕСКИХ АСПЕКТОВ И ОТНОШЕНИЕ СТУДЕНТОВ К ДИСТАНЦИОННОЙ ФОРМЕ ОБРАЗОВАНИЯ
}

Аннотация. В статье приведены итоги исследования отношения студентов к системе дистанционного образования. Обозначены проблемы и недостатки такого обучения.

Ключевые слова: дистанционное образование, студенты, образовательная платформа, самостоятельные занятия.

Korshunova O.S., ORCID: 0000-0002-5602-3688

Novosibirsk State University of Economics and Management, Novosibirsk, Russia

\section{RESEARCH OF PSYCHOLOGICAL ASPECTS AND ATTITUDE OF STUDENTS TO DISTANCE EDUCATION}

Annotation. The article presents the results of the study of the attitude of students to the distance education system. Problems and disadvantages of such training are identified.

Keywords: distance education, students, educational platform, independent classes.

Высшее образование по дисциплине физическая культура в ВУЗе - это последняя ступень в вертикали физического воспитания молодежи. И если в школе предмет физическая культура носил - больше оздоровительный характер, то в вузе это однозначно образовательный предмет. Тем пагубнее влияет на полученные знания удаленная форма организации образования по нашей дисциплине. Быстро меняющиеся условия в образовательном пространстве высшей школы, вынуждают преподавателей соответствовать предложенному темпу, или сходить с дистанции. Переход на удаленную систему преподавания в 2020 году дал возможность освоить новое пространство и приобрести новые навыки, работы on-line. И преподаватели, даже такой сугубо практической дисциплины, как физическое воспитание были вынуждены освоить дистанционные способы работы со студентами. Но изменение в образовательном процессе с переходом на дистанционную систему коснулось, в первую очередь студентов. Особенно тревожит ситуация со студентами младших курсов. Если третьи и старшие курсы уже получили соответствующие общеобразовательные компетенции по ФК на практических и методических занятиях, то первокурсники на удаленной форме организации учебного процесса, маловероятно, что приобретут нужные навыки.

Темой нашего исследования стал вопрос отношения студентов к дистанционной форме организации учебного процесса именно по нашей кафедре физического воспитания и спорта. В исследовании приняли участия студенты 1-3 курса обучения по элективным дисциплинам по физической культуре и спорту. Возможность выбора элективов в нашем вузе наступает во втором семестре обучения. Первокурсники в первом семестре занимаются по программе 
физической культурой и спортом, знакомятся с нашей базой, формируют свои приоритеты. Затем пишут заявление и со второго семестра уже занимаются выбранным видом физической активности.

Исследование проводилось методом анкетирования, сравнивались ответы первого, второго и третьего курса обучения. На первом курсе приняли участие 250 респондентов, на втором 220 и на третьем 198. В анкете были заданы следующие вопросы:

1. Дистанционное образование по кафедре ФВиС соответствует ожидаемым результатам.

2. Удаленная форма образования по элективным дисциплинам физической культуры и спорта, приемлема?

3. Вы предпочли бы дистанционную форму организации учебного процесса, перед очными занятиями.

Ответы принимались максимально краткие: «да»; «нет». Анализируя полученные результаты исследования показали такую картину:

Студенты первого курса наиболее часто ответили на все предложенные вопросы отрицательным ответом. В процентном соотношении это выглядит так:

По первому вопросу - (дистанционное образование по кафедре ФВиС соответствует ожидаемым результатам) 95\% ответили «Нет»; 5\% ответили «Да»

По второму вопросу - (удаленная форма образования по элективным дисциплинам физической культуры и спорта, приемлема?) процент отрицания был еще выше... 98\% выбрали ответ «Нет»; 2\% ответ «Да». И на последний вопрос (вы предпочли бы дистанционную форму организации учебного процесса, перед очными занятиями?) «Да» выбрали $32 \%$; «нет» оставшиеся 68\%. Что резонирует с ответами на второй вопрос.

Получается, осознавая, что такая форма учебы не принесет им желаемого результата, согласны получать образование именно так довольно большая часть первокурсников (32\%).

Студенты второго курса, ожидаемо, ответили на эти же самые вопросы и показали более низкие процентные результаты. По первому вопросу - (дистанционное образование по кафедре ФВиС соответствует ожидаемым результатам) 60\% ответили «Нет» 40\% ответили «Да». По второму вопросу - (удаленная форма образования по элективным дисциплинам физической культуры и спорта, приемлема?) процент отрицания был еще выше: 80 выбрали ответ «Нет»; 20\% ответ «Да». И на последний вопрос (вы предпочли бы дистанционную форму организации учебного процесса, перед очными занятиями?) «Да» выбрали 57\%; «Нет» оставшиеся 43\%. Студенты второго курса осознанно понимают, что практические занятия элективными дисциплинами по физической культуре и спорту больше принесут пользы для формирования компетенций по нашей дисциплине. Что движение, влияет на здоровье и служит стержнем всего образовательного процесса и будущей профессии [1, с. 146]. И тем ни менее готовы заменить практические занятия на формальные получения зачета по этой дисциплине.

Третьекурсники, по статистике посещения учебных занятий, имеют достаточно низкие показатели, поэтому и ответы на предложенные вопросы были оправданы этими показателями посещаемости. По первому вопросу - (дистанционное образование по кафедре ФВиС соответствует ожидаемым результатам) 55\% ответили «Нет» 45\% ответили «Да». По второму вопросу - (удаленная форма образования по элективным дисциплинам физической культуры и спорта, приемлема?) процент отрицания был еще выше: 70\% выбрали ответ «Нет»; 30\% ответ «Да». И на последний вопрос (вы предпочли бы дистанционную форму организации учебного процесса, перед очными занятиями?) «Да» выбрали 85\%; «Нет» оставшиеся 15\%. 
Подводя итоги проведенного исследования можно сделать неутешительные, но характерные выводы: Студенты старших курсов теряют интерес к практическим занятиям физического воспитания, понимая при этом, что качество полученных знаний на дистанционной форме организации учебного процесса не сформирует заявленных ВУЗом компетенций по этой дисциплине. Формирование универсальных компетенций в процессе реализации указанных дисциплин обусловлена повышением требований к уровню подготовки специалиста в целях обеспечения полноценной социальной и профессиональной деятельности [2, c. 112].

Остается надеется, что молодежь дополнительно занимается фитнесом, получая физическую нагрузку в удобное для них время и в удобном для них месте. Но даже это не является основой для формирования знаний по своей профессиограмме в будущем. Общекультурные компетенции, предусмотренные программой высшей школы, не могут сформироваться вне учебного заведения. Ранее нами было проведено исследование, что физической нагрузки благотворно сказывается на физическое состояние и успеваемость студентов [3, с. 126]. Поэтому системность физической активности предусмотренная нашим учебным расписание благотворно влияет и на качество знаний у студентов и по другим предметам.

Ценность практических занятий по ФК состоит не только в приобретении и сбережении здоровья, но и в том, что это эффективный инструмент формирования личности и совершенствования характера, помогающего молодому человеку успешно социализироваться и адаптироваться в профессиональном сообществе [4, с. 177].Тенденция руководства современных бизнес компаний различного уровня иметь в своем составе не только высокопрофессиональных специалистов, но и физически привлекательных, здоровых, мотивированных на активный и здоровый образ жизни молодых людей [5, с. 349].

Физическое воспитание - это образование, формирование компетенций, двигательной активности, поведенческого стереотипа, для дальнейшей качественной жизни и профессиональной деятельности наших выпускников.

\section{Литература}

1. Белявцева О.С., Федорова Н.Ю. Вопросы здоровьесбережения в высшей школе: укрепление осанки и воспитания выносливости // Философия образования. 2019. Т. 19. № 1. C. $145-155$.

2. Шулаков А.В., Скворцова С.О. Педагогические условия формирования универсальных компетенций у студентов экономического вуза в процессе проведения занятий по физической культуре. Сибирский педагогический журнал. 2020. № 2. С. 111-117.

3. Скворцова С.О. Формирование навыков здоровьясбережения у студентов первокурсников // Физическая культура, здравоохранение и образование материалы XI Международной научно-практической конференции, посвященной памяти В.С. Пирусского. Под ред. В.Г. Шилько. 2017. С. 124-127.

4. Страхова И.Б. Валеологическое образование как фактор восстановления здоровья студентов // Интерэкспо ГЕО-Сибирь-2014. Х Междунар. науч. конгр.: Междунар. науч. конф. «Глобальные процессы в региональном измерении: опыт истории и современность»: сб. материалов. в 2 т. (Новосибирск, 8-18 апреля 2014 г.). Новосибирск: СГГА, 2014. Т. 2. С. 176178. 
5. Перминов О.А. Исследование проблем, влияющих на качество учебного процесса по физическому воспитанию студентов // Перспективные направления в области физической культуры, спорта и туризма: Материалы IX Всероссийской научно-практической конференции. 2019. С. 348-350.

(C) Кориунова O.C., 2021 